\title{
Helicobacter spp. infection in dogs is not associated with changes in epithelial proliferation or E-cadherin expression in gastric mucosa
}

\section{Infecção por Helicobacter spp. em cães não está associada com alterações na proliferação epitelial ou na expressão de E-caderina na mucosa gástrica}

\author{
Luciana Sayuri Takemura ${ }^{1}$; Romulo Estangari Lot ${ }^{2}$; \\ Pedro Luiz de Camargo ${ }^{3}$; Elisângela Olegário da Silva ${ }^{4}$; Amauri Alcindo Alfieri ${ }^{5}$; \\ Ana Paula Frederico Rodrigues Loureiro Bracarense ${ }^{5 *}$
}

\begin{abstract}
Helicobacter pylori infection causes gastritis and can induce gastric adenocarcinoma and MALT lymphoma in humans. The aim of this study was to determine in dogs whether there is an association between Helicobacter spp. infection in gastric mucosa, histological lesions, including epithelial cell proliferation and cell adhesion. Gastric biopsies of 12 dogs with gastric disturbances and 25 healthy dogs were evaluated. Warthin-Starry staining (WS) and PCR assay were performed to confirm the presence of helicobacteria. The Helicobacter species were determined by PCR assay with speciesspecific primers for $H$. heilmannii, $H$. bizzozeronii or $H$. salomonis, $H$. felis and $H$. pylori. Mucosal lesions were evaluated by haematoxylin and eosin (HE) and epithelial proliferation was determined by AgNOR and PCNA methods. Cell adhesion was evaluated by the expression of E-cadherin by epithelial cells. Helicobacter spp. was confirmed in 75.7\% (28/37) and 73.0\% (27/37) of the samples by WS and PCR, respectively. H. bizzozeronii was the species most frequently detected (37\%); co-infection was observed in six $(22 \%)$ dogs. Histological changes in the lamina propria included mild chronic gastritis, fibrosis, glandular degeneration, and presence of lymphoid aggregates. There was a significant association between $H$. heilmannii infection and the presence of lymphoid follicles $(\mathrm{p}<0.046)$. In this study no significant change in epithelial proliferation or E-cadherin expression were detected in the gastric mucosa of dogs infected with Helicobacter spp.
\end{abstract}

Key words: Dog, gastric lesion, Helicobacter spp., epithelial proliferation, cell adhesion

\section{Resumo}

Infecção por Helicobacter pylori provoca gastrite e pode induzir adenocarcinoma gástrico e linfoma tipo MALT em seres humanos. O objetivo deste estudo foi determinar se existe associação entre infecção por Helicobacter spp. na mucosa gástrica de cães e lesões histológicas, incluindo proliferação epitelial e adesão celular. Foram avaliadas biópsias de 12 cães com distúrbios gástricos e de 25 cães saudáveis. A coloração de Warthin-Starry (WS) e o método de PCR foram utilizados para confirmar a presença de helicobactérias. As espécies de Helicobacter foram determinadas por PCR com primers

\footnotetext{
1 Prof. Adjunto, Universidade Norte do Paraná, UNOPAR, Londrina, PR. E-mail: lucianatakemura@yahoo.com.br

${ }^{2}$ Prof. Assistente, Faculdade de Medicina Veterinária e Zootecnia de Garça, Garça, SP. E-mail: romulovet@yahoo.com.br

${ }^{3}$ Prof. Dr. Associado, Dept ${ }^{\circ}$ de Clínicas Veterinárias. Universidade Estadual de Londrina, UEL, Londrina, PR. E-mail: p.camargo@ uel.br

${ }^{4}$ Discente de Mestrado em Ciência Animal, UEL, Londrina, PR. E-mail: elivet02@gmail.com

${ }^{5}$ Profs. Drs. Associado, Dept ${ }^{\circ}$ Medicina Veterinária Preventiva, UEL, Londrina, PR. E-mail: alfieri@uel.br; anapaula@uel.br

* Author for correspondence
} 
espécie-específicos para $H$. heilmannii, H. bizzozeronii ou $H$. salomonis, $H$. felis e $H$. pylori. As lesões da mucosa foram avaliadas por hematoxilina e eosina (HE) e a proliferação epitelial foi determinada pelos métodos AgNOR e PCNA. A adesão celular foi avaliada por meio da expressão de E-caderina nas células epiteliais. Helicobacter spp. foi confirmado em 75,7\% (28/37) e 73,0\% (27/37) das amostras por WS e PCR, respectivamente. H. bizzozeronii foi a espécie mais frequentemente detectada (37\%); e coinfecção foi observada em seis $(22 \%)$ cães. As alterações histológicas na lâmina própria foram gastrite crônica discreta, fibrose, degeneração glandular e presença de agregados linfóides. Houve associação significativa entre a infecção por $H$. heilmannii e a presença de folículos linfóides $(\mathrm{p}<0,046)$. Neste estudo, nenhuma alteração significativa foi verificada na proliferação epitelial ou na expressão de E-caderina na mucosa gástrica de cães infectados com Helicobacter spp.

Palavras-chave: Cão, lesão gástrica, Helicobacter spp., proliferação epitelial, adesão celular

\section{Introduction}

Helicobacter pylori causes chronic gastritis and is a strong risk factor for gastric adenocarcinoma and MALT lymphoma in humans (UEMURA et al., 2001; XIA; TALLEY, 2001). Dogs and cats are commonly infected with tightly coiled "large Helicobacter species" measuring 5-15 $\mu \mathrm{m}$ that are morphologically different from $H$. pylori (JALAVA et al., 1997). The species that have been reported in the gastric mucosa of dogs are $H$. felis, $H$. bizzozeronii, $H$. salomonis, $H$. heilmannii (HÄNNINEN et al., 1996; JALAVA et al., 1997), and, more recently, $H$. cynogastricus (VAN DEN BULCK et al., 2006). Helicobacter heilmannii is prevalent in many animal species and causes gastric disease in a small percentage of human beings (JALAVA et al., 2001). Specific pathogen-free mice inoculated with human and animal isolates of $H$. heilmannii developed gastric MALT lymphoma (O'ROURKE et al., 2004). Moreover, H. felis causes a chronic inflammation gradually progressing to gastric neoplasia in some strains of mice, which are an established model of $H$. pylori-induced gastric disease in human beings (CUI et al., 2004).

In contrast to $H$. pylori infection in humans, little is known about pathogenic mechanisms of gastric Helicobacter in dogs, although the prevalence of infection by several species is high (67 to $100 \%)$ (NEIGER; SIMPSON, 2000). Histological findings, such as mild to moderate gastritis, reduction in mucus production, glandular degeneration, interstitial edema, fibrosis of lamina propria, hyperplasia, vacuolization, and necrosis of parietal cells were described in dogs naturally infected by Helicobacter species (HERMANNS et al., 1995; YAMASAKI; SUEMATSU; TAKAHASHI, 1998). In cats, gastric Helicobacter infection is associated with an increase in the number of lymphoid follicles (STRAUBINGER et al., 2003; TAKEMURA et al., 2009).

Increased gastric epithelial proliferation and apoptosis have been reported in humans infected by $H$. pylori, and both events play an important role in gastrointestinal epithelial cell turnover and carcinogenesis (DE FREITAS et al., 2004). An increase in cell proliferation is a pre-neoplastic change that may be an indicator of the risk of gastric neoplasia (STEININGER et al., 1995). Infection by $H$. heilmannii in cats is associated with an increase in gastric epithelial proliferation (TAKEMURA et al., 2009) and the development of gastric lymphoma (BRIDGEFORD et al., 2008). Changes in cadherin expression, a transmembrane glycoprotein of junctional complexes, have been linked to cell growth, carcinogenesis, metastasis, and development of gastric cancer (CHAN, 2006). By contrast, few studies have investigated the relationship between Helicobacter infection, gastritis, and epithelial proliferation in dogs (SAPIERZYŃSKI; MALICKA, 2004). At this time, there are no studies demonstrating the effects of gastric Helicobacter spp. on cell adhesion in dogs. Therefore, the goal of this study was to evaluate whether there is an association between infection by specific Helicobacter species, gastric 
lesions, epithelial proliferation, and expression of E-cadherin in the gastric mucosa of dogs.

\section{Material and Methods}

\section{Specimens}

Samples of gastric mucosa were collected from 37 pet dogs (15 males and 22 females) aged from 6 months to 12 years. Twenty-five of these dogs were asymptomatic, and 12 animals had histories of chronic and sporadic vomiting. None of the animals had received medication in the preceding month. The study was approved by the institution's Ethics Committee for Animal Experimentation, and samples were collected with consent of the animals' owners.

Food was withheld for $12 \mathrm{~h}$ before gastroscopy and gastric biopsy. The patients were anaesthetized with propofol ( $5 \mathrm{mg} / \mathrm{Kg}$ ). The biopsy procedure was performed with a flexible pediatric endoscope and, two samples of mucosa from the antrum, corpus and fundus were collected. These samples were fixed in Bouin's solution for $24 \mathrm{~h}$, embedded in paraffin wax and processed routinely. Sections were stained with haematoxylin and eosin (HE) and WarthinStarry (WS) methods to detect histological changes and Helicobacter infection, respectively. For the molecular assays, another sample from each gastric region was placed into a DNase- and RNase-free tube and immediately frozen at $-20^{\circ} \mathrm{C}$ until DNA extraction.

\section{Polymerase Chain Reaction (PCR) Assay}

DNA extraction was performed according to Takemura et al. (2009). All the samples were tested for Helicobacter genus. The positives dogs were tested for $H$. heilmannii, $H$. bizzozeronii or $H$. salomonis, H. felis and H. pylori. The genes targeted for these species of Helicobacter, the primer sequences, the size of amplified fragments (base pairs, bp) and the annealing temperatures of the reactions were described elsewhere (TAKEMURA et al., 2009).

\section{Histological assessment}

The numbers of lymphoid aggregates and inflammatory cells, as well as gastric Helicobacter colonization density and location were evaluated. The assessment was conduct with a visual scale based on the Sidney system (DIXON et al., 1996), as adapted and standardized for dogs by Happonen et al. (1998).

Assessment of Cell Proliferation and E-cadherin expression

Epithelial proliferation was assessed by staining nucleolar organiser regions (NORs) with colloidal silver nitrate (the AgNOR method) and by proliferating cell nuclear antigen (PCNA) technique. The AgNOR assay was performed in 20 of the 37 dogs according to Ploton et al. (1986). Group 1 (G1) consisted of nine uninfected dogs, and Group 2 (G2) were from 11 dogs positive for Helicobacter infection.

Immunohistochemistry with PCNA and E-cadherin was performed on 28 samples (21 infected dogs and seven uninfected). The sections were deparaffinized with xylene and dehydrated and immersed in citrate buffer ( $\mathrm{pH}$ 6.0). Endogenous peroxidase activity was blocked by incubation in methanol $/ \mathrm{H}_{2} \mathrm{O}_{2}$ solution. The sections were incubated overnight at $4^{\circ} \mathrm{C}$ with the primary antibody (anti-PCNA, Clone PC-10 or anti-Ecadherin Clone 4A2C7, Zymed, San Francisco, CA, diluted $1: 200$ or 1:50, respectively). The secondary antibody (Kit Super Picture ${ }^{\mathrm{TM}}$ Zymed, San Francisco, CA) was applied followed by the addition of a chromogen (3, 3'-diaminobenzidine). Finally, the tissue sections were counterstained with haematoxylin and mounted on coverslips using a permanent mounting medium. PCNA-positive cells were counted in 100 nuclei in at least four 
random fields, with positive counts determined by the staining intensity. Labeling index percentage (LI\%) was measured by the rate of the number of positive and strongly positive cells per total number of observed cells. Normal E-cadherin expression was considered when a strong and homogeneous staining was observed. Weak and heterogeneous staining was classified as reduced expression.

\section{Statistical Analysis}

The association between colonization density, inflammatory infiltrate, and species of Helicobacter in the gastric regions was evaluated by the Kruskal-Wallis test. The Fisher's exact test was used to determine whether Helicobacter infection was associated with clinical condition, gastritis, glandular epithelial degeneration, lamina propria fibrosis or presence of lymphoid aggregates. The association between the species of Helicobacter with glandular epithelial degeneration and presence of lymphoid aggregates was analyzed by the same test. The relationship between infection by Helicobacter spp. and epithelial proliferation, and expression of E-cadherin was evaluated by analysis of variance (ANOVA). Gastritis was correlated with colonization density, cell proliferation and E-cadherin expression by Pearson test. All tests were performed with Statistics Analysis Systems software (SAS, Cary, NC). Significance was set at $\mathrm{p}<0.05$.

\section{Results}

PCR Assay

Samples from 27 (73\%) dogs generated a 399 bp amplicon in a Helicobacter genus specific PCR assay. Helicobacter bizzozeronii or $H$. salomonis was present in 10 (37\%) dogs; H. felis was present in seven (26\%); and $H$. heilmannii was present in five (19\%) (Figure 1A). Thirteen (48\%) dogs were positive for Helicobacter but negative in each of the four species-specific PCR assays. Co-infection occurred in six (22.2\%) animals. Four samples had a mixed infection with $H$. bizzozeronii or $H$. salomonis and $H$. felis, and two were positive for $H$. bizzozeronii or H. salomonis, H. felis, and H. heilmannii.

\section{Histological findings}

Large and tightly coiled Helicobacter were seen in $28(75.7 \%)$ dogs by WS staining. Seven samples were from dogs with clinical signs of gastric disease, and 21 were from healthy dogs. There was no significant association between gastric infection and clinical condition $(\mathrm{p}=0.116)$. The bacteria were located in mucus, gastric pits, and glands, as well as within the cytoplasm of parietal cells. There was no significant difference in colonization density among the three gastric regions evaluated $(\mathrm{p}=0.415)$.

Data related to histological findings are presented in Table 1. The gastric antrum and corpus were the regions most affected by lymphocyte infiltration in the lamina propria; however, there was no significant difference in the severity of inflammation among the three gastric regions $(p=0.132)$. No correlation between the colonization density and inflammation could be substantiated ( $\mathrm{p}>0.05$ ). In addition, no association was observed between infecting species of Helicobacter and the degree of inflammatory infiltration $(\mathrm{p}=0.15)$. 
Figure 1. A) Agarose gel 2.0\% with ethidium bromide electrophoresis patterns for Helicobacter spp. Polymerase chain reaction products: PM: $123 \mathrm{bp}$ molecular weight marker; Hsp: positive gastric sample for Helicobacter genus (399 bp); NC: negative control; Hf: positive gastric sample for $H$. felis (241 bp); Hb: positive gastric sample for $H$. bizzozeronii (499 bp); Hh: positive gastric sample for $H$. heilmannii (580 bp). B) Fibrosis and glandular degeneration in gastric corpus, HE, 10X. C) Immunohistochemical staining for PCNA in gastric mucosa. Positive cells (head arrow) and strongly positive cells (arrow) of fovea, 40X. D) Immunohistochemical staining for E-cadherin in gastric mucosa. Strong and homogeneous staining (black arrow), 40X.

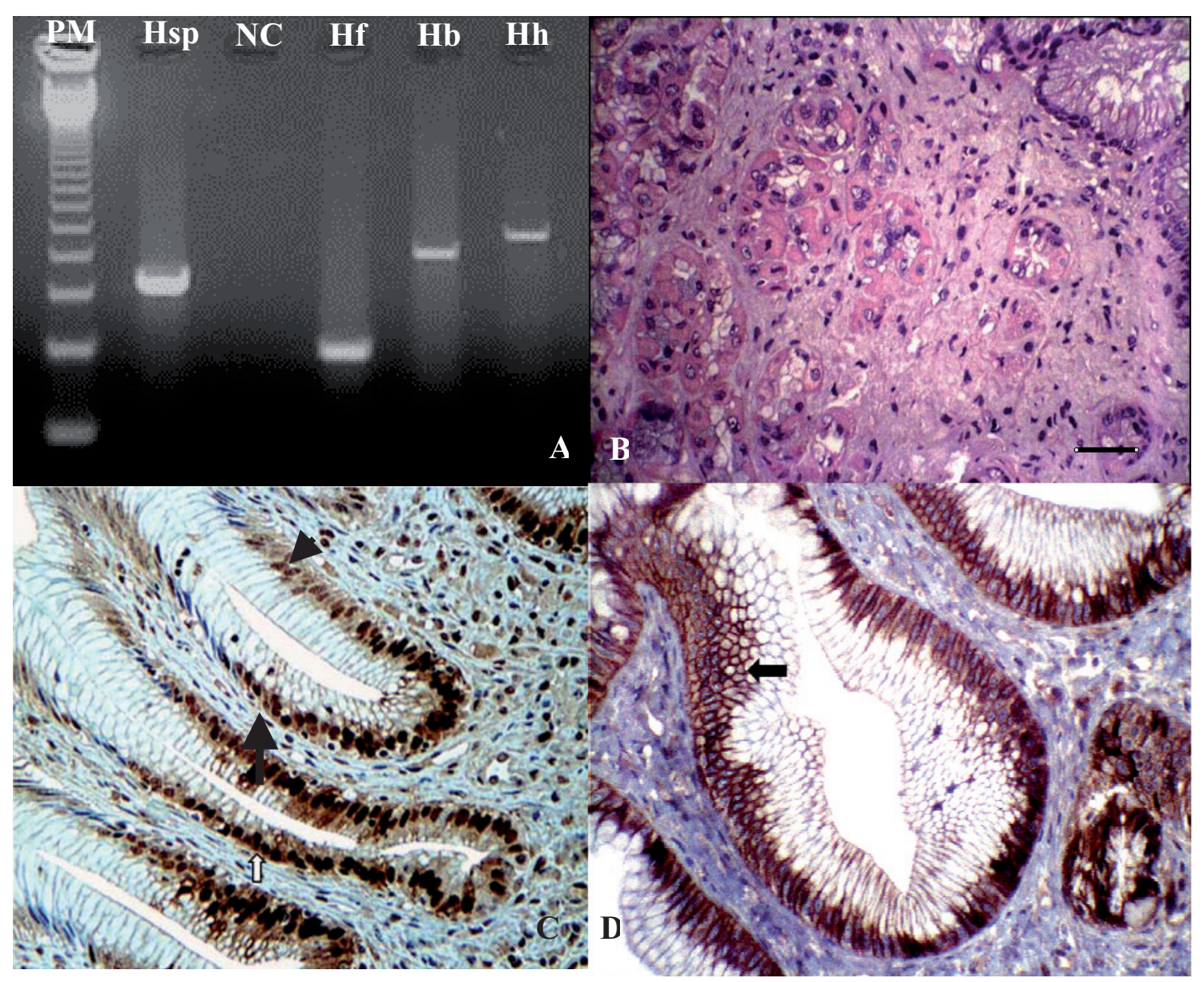

Source: Elaboration of the authors. 
Table 1. Microscopical findings in three gastric regions of dogs infected by gastric Helicobacter spp.

\begin{tabular}{lcccccc}
\hline \multirow{2}{*}{ Microscopical findings } & \multicolumn{6}{c}{ Frequency of microscopical findings } \\
\cline { 2 - 6 } & \multicolumn{5}{c}{ Infected dogs (n=28) } & \multicolumn{3}{c}{ Uninfected dogs (n=9) } \\
\cline { 2 - 6 } & Antrum & Corpus & Fundus & Antrum & Corpus & Fundus \\
\hline$\quad$ Epithelial mucosa & 0 & 3 & 1 & 0 & 0 & 1 \\
$\quad$ Erosion & & & & & & \\
$\quad$ Lamina propria & 10 & 10 & 10 & 1 & 2 & 1 \\
Lymphoid aggregates & 17 & 16 & 10 & 2 & 5 & $2^{*}$ \\
Mild inflammatory infiltrate & 16 & 11 & 12 & 5 & 0 & 2 \\
Mild fibrosis & 4 & 0 & 3 & 1 & 1 & 0 \\
Severe fibrosis & 1 & 1 & 2 & 0 & 0 & 1 \\
Edema & & & & & & \\
Gastric glands & 15 & 8 & 11 & 5 & 1 & 2 \\
Glandular degeneration & & &
\end{tabular}

*Only eight samples of fundic mucosa were evaluated from uninfected dogs.

Source: Elaboration of the authors.

The association between lymphoid follicles within the lamina propria and Helicobacter infection and/or chronic gastritis has been evaluated. There were no more than two lymphocyte aggregates per specimen. These follicles were found in all three gastric regions in five dogs, one of which was uninfected. There was no significant association between gastric infection and the presence of lymphoid follicles $(\mathrm{p}=0.06)$ when Helicobacter spp. infection was considered. By contrast, $H$. heilmannii infection was found to be associated with lymphoid aggregates $(\mathrm{p}=0.046)$.

Other histological lesions were also observed, including mild to severe fibrosis, glandular degeneration, erosion, and interstitial edema. All the samples, even those from dogs not infected with Helicobacter, presented at least one of these lesions. Fibrosis in the lamina propria was frequently observed, both focally and diffusely. Glandular degeneration was characterized by vacuoles within the cytoplasm and enlarged nuclei in epithelial cells. In 18 infected dogs and four uninfected dogs, fibrosis and glandular degeneration occurred simultaneously (Figure 1B). There was no association between gastric Helicobacter infection and gastritis $(\mathrm{p}=0.37)$, glandular degeneration $(\mathrm{p}$ $=0.73)$, and fibrosis $(\mathrm{p}=0.43)$. In addition, there was no significant difference among the specific species of Helicobacter in terms of association with glandular degeneration $(\mathrm{p}>0.05)$.

\section{Cell proliferation}

AgNOR proteins appeared in light microscopy as irregular black dots in the nucleus. The mean values obtained in epithelial proliferation analysis are given in Table 2. There was no significant difference among the variables analyzed.

The distribution of PCNA LI\% expression in different regions of gastric mucosa is shown in Table 3. PCNA expression was observed predominantly in the fovea (Figure 1C). There was no significant difference in cell proliferating index among the three gastric regions or in the intensity of PCNA expression between infected and uninfected dogs. In addition, there was no correlation between gastric inflammation and PCNA-staining in any of the three gastric regions (antrum: $r=0.30$; corpus: $r=0.27$; fundus: $r=-0.18$ ). 
Table 2. Mean AgNOR number per cell, mean size of individual AgNOR dots and mean entire AgNOR area per epithelial cell in infected and uninfected dogs.

\begin{tabular}{ccccccc}
\hline \multirow{2}{*}{ Parameter } & \multicolumn{5}{c}{ Mean \pm Standard deviation } \\
\cline { 2 - 6 } & Antrum & Corpus & Fundus & Antrum & Corpus & Fundus \\
\hline Number of NORs & $1.31 \pm 0.51$ & $1.31 \pm 0.50$ & $1.26 \pm 0.47$ & $1.54 \pm 0.71$ & $1.51 \pm 0.68$ & $1.50 \pm 0.68$ \\
NOR-dot area $\left(\mu \mathrm{m}^{2}\right)$ & $1.18 \pm 0.58$ & $1.10 \pm 0.49$ & $1.03 \pm 0.42$ & $0.71 \pm 0.40$ & $0.70 \pm 0.33$ & $0.68 \pm 0.25$ \\
NOR area/cell $\left(\mu \mathrm{m}^{2}\right)$ & $1.30 \pm 0.44$ & $1.22 \pm 0.40$ & $0.50 \pm 0.23$ & $0.53 \pm 0.24$ & $0.64 \pm 0.29$ & $0.60 \pm 0.24$ \\
\hline
\end{tabular}

Source: Elaboration of the authors.

Table 3. Mean and standard deviation of intensity of PCNA-staining in gastric mucosa of uninfected dogs and infected dogs by Helicobacter spp.

\begin{tabular}{lcccccc}
\hline \multicolumn{5}{c}{ Mean \pm Standard deviation } \\
\hline & \multicolumn{3}{c}{ Uninfected dogs } & \multicolumn{3}{c}{ Infected dogs } \\
\hline $\begin{array}{l}\text { Positive cells } \\
\begin{array}{l}\text { Strongly positive } \\
\text { cells }\end{array}\end{array}$ & $74.5 \pm 11.79$ & $72.00 \pm 13.61$ & $71.5 \pm 8.51$ & $70.86 \pm 16.16$ & $63.86 \pm 9.82$ & $52.93 \pm 22.09$ \\
\hline
\end{tabular}

Source: Elaboration of the authors.

Expression of E-cadherin

All of the gastric mucosa samples showed expression of E-cadherin (Table 4). Strong staining was predominant (Figure 1D), but there was no significant difference in E-cadherin-expression between infected and uninfected groups. In addition, there was no correlation between gastric inflammation and E-cadherin-expression in any of the three gastric regions (antrum: $r=-0.15$; corpus: $r=-0.04$; fundus: $r=-0.17$ ).

Table 4. Frequency of infected and uninfected dogs according to intensity of E-cadherin-staining in three gastric regions.

\begin{tabular}{lcccccc}
\hline & \multicolumn{3}{c}{ Uninfected dogs (n=7) } & \multicolumn{3}{c}{ Infected dogs (n=21) } \\
\hline & Antrum & Corpus & Fundus & Antrum & Corpus & Fundus \\
\hline E-cadherin expression & & & & & & \\
Strong staining & 05 & 07 & 06 & 20 & 18 & 18 \\
Weak staining & 02 & 0 & 01 & 01 & 03 & 03 \\
\hline
\end{tabular}

Source: Elaboration of the authors. 


\section{Discussion}

A high occurrence of gastric Helicobacter (76\%) infection has been detected as described in other studies in various countries (EATON et al., 1996; HAPPONEN et al., 1998; YAMASAKI; SUEMATSU; TAKAHASHI, 1998). Different species of Helicobacter can infect the gastric mucosa of dogs, and mixed infections are also reported (VAN DEN BULCK et al., 2005). In this study, either H. bizzozeronii or $H$. salomonis was identified in $37 \%$ of the positive samples as single species or in co-infection with $H$. heilmannii and/ or $H$. felis. As in previous reports, $H$. bizzozeronii is the most prevalent species in dogs (CATTOLI et al., 1999; VAN DEN BULCK et al., 2005). Interestingly, the frequency of $\mathrm{H}$. felis in pet dogs was much lower than we have observed previously in roaming dogs (CAMARGO et al., 2002).

Twenty-eight samples were positive for the genus Helicobacter but negative for the species tested, indicating that other Helicobacter species could be infecting the gastric mucosa of dogs. Flexispira rappini, H. bilis (NEIGER et al., 1999) and $H$. cynogastricus (VAN DEN BULCK et al., 2006) show morphologic features under light microscopy that resemble other non-H. pylori species (VAN Den BULCK et al., 2005). H. pylori, the species most commonly implicated in human gastritis, was not detected in dogs, a result also found in previous studies (CAMARGO et al., 2002; CATTOLI et al., 1999; EATON et al., 1996). Considering the close contact between pet dogs and humans, this finding indicates that dogs do not represent a source of $H$. pylori infection.

Histological gastritis was observed in 29 dogs, 21 of which were infected with Helicobacter spp. Gastric inflammation is common both in healthy dogs and in dogs with gastric disturbance (HAPPONEN et al., 1998; HERMANNS et al., 1995; YAMASAKI; SUEMATSU; TAKAHASHI, 1998). Lymphocytic infiltrate was not associated with Helicobacter infection or the degree of colonization density, in agreement with previous studies
(EATON et al., 1996; SIMPSON et al., 1999b). Lymphoid aggregates were frequently observed in our samples, and an increase in their number was associated with $H$. heilmannii infection, but not with gastritis. Simpson et al. (1999a) observed an increase in the number of lymphoid follicles and a severe chronic gastritis in specific-pathogen-free dogs inoculated with $H$. felis. In addition, lymphoid aggregates were associated with gastric infection by $H$. pylori in humans and large Helicobacter species in cats (OTTO et al., 1994; TAKEMURA et al., 2009). This association was characterized as deriving from an immune response to Helicobacter infection (STRAUBINGER et al., 2003), and as a risk factor for the development of MALT lymphoma (BRIDGEFORD et al., 2008; THIEDE et al., 1997).

Glandular degeneration and fibrosis were common findings and were frequently accompanied by mild inflammatory infiltrate. These gastric lesions were not associated with the degree of colonization density, but the lesions were more frequently seen in the stomach of infected dogs. Hermanns et al. (1995) observed a significant association between colonization density and the severity of gastritis, glandular degeneration, and lesions on superficial gastric epithelial cells in cats. Helicobacter felis and $H$. bizzozeronii induced loss of parietal cells in gerbils (DE BOCK et al., 2006), and these species have been observed in the parietal cell canaliculi of dogs and cats (PEYROL et al., 1998). These findings suggest that glandular degeneration could be related either to Helicobacter virulence factors or to the host immune response. In pigs, a relationship between Helicobacter infection, epithelial degeneration, and epithelial proliferation of pars esophagea has been demonstrated (PREZIOSI; SARLI; MARCATO, 2000).

A large number of epidemiological studies indicated that $H$. pylori infection is closely related to the development of gastric cancer (UEMURA et al., 2001; XIA; TALLEY, 2001), leading this species to be classified as a carcinogen in the human stomach (IARC, 1994). Mucosal hyperproliferation 
increases the risk of gastric adenocarcinoma and has been demonstrated in $H$. pylori-infected gastric tissue in humans (CORREA, 1996; PARSONNET et al., 1991). One mechanism by which H. pylori induces carcinogenesis is by altering cellular turnover. Dogs are commonly infected with different species of Helicobacter (NEIGER et al., 1999, VAN Den BULCK et al., 2005); but only one study had investigated the effect of gastric Helicobacter on gastric epithelial cell proliferation in dogs (SAPIERZYŃSKI; MALICKA, 2004). Using histochemical and immunohistochemical assays, this study detected no increase in epithelial proliferation in the gastric mucosa of dogs infected with Helicobacter spp.

An increase in the number of NORs, accompanied by a decrease in the number of PCNApositive cells, was observed in infected animals; however, the frequency of these changes showed no significant difference between infected and uninfected dogs. We have demonstrated previously that in cats, Helicobacter infection induces an increase in the number of NORs in epithelial cells (TAKEMURA et al., 2009). In addition, increased epithelial proliferation in the gastric antrum was reported in Helicobacter-infected dogs with gastritis (SAPIERZYŃSKI; MALICKA, 2004). The differences in these findings could be the result of the species of Helicobacter, species-specific virulence factors or the release of cytokines by inflammatory cells (PEEK JUNIOR et al., 2000).

Membranous cadherin staining is strong in the normal gastric epithelium but gradually decreases in intensity with increasing severity of diseases, from chronic atrophic gastritis to intestinal metaplasia, dysplasia and adenocarcinoma (CHAN, 2006). Expression of E-cadherin decreases early in the formation of precancerous lesions that develop into gastric cancer, suggesting E-cadherin may play an early role in the development of gastric cancer (CHAN et al., 2003). The normal cadherin expression levels found in this study indicate that neither Helicobacter spp. infection nor mild chronic gastritis affects E-cadherin expression in dogs. This finding is contradictory with the results in patients with gastritis and $H$. pylori infection (YU et al., 2000 ) as wells as for those with gastric cancer (LIU et al., 2005). This difference is probably related to the intensity of inflammatory infiltrate and infecting species encountered in dogs.

In conclusion, the frequency of infection with Helicobacter spp. varies by study and the method of diagnosis, but it is known that H. bizzozeronni is more commonly identified in the gastric mucosa of dogs. As in other animals, H. heilmannii infection was found to be associated with increased numbers of lymphoid follicles in dogs. Changes in epithelial proliferation and E-cadherin expression in dogs were not seen, most likely because the grade of gastric inflammation is not associated with such changes.

\section{Acknowledgments}

L. S. T. was supported by a doctoral fellowship financed by CNPq. A.P.F.R.L. Bracarense and A.A. Alfieri were supported by a research fellowship financed by CNPq.

\section{References}

BRIDGEFORD, E. C.; MARINI, R. P.; FENG, Y.; PARRY, N. M. A.; RICKMAN, B.; FOX, J. G. Gastric Helicobacter species as a cause of feline gastric lymphoma: a viable hypothesis. Veterinary Immunology and Immunopathology, Amsterdam, v. 123, n. 1-2, p. 106-113, 2008.

CAMARGO, P. L.; BRACARENSE, A. P. F. R. L.; ALFIERI, A. A.; HAGIWARA, M. K. Helicobacter spp. in dogs and cats from South Brazil. In: WORLD VETERINARY CONGRESS, 27., 2002, Tunis. Proceedings...Tunis: [s.n], 2002. p. 255.

CATTOLI, G.; VAN VUGT, R.; ZANONI, R. G.; SANGUINETTI, V.; CHIOCCHETTI, R.; GUALTIERI, M.; VANDENBROUCKE-GRAULS, C. M. J. E.; GAASTRA, W.; KUSTERS, J. G. Occurrence and characterization of gastric Helicobacter spp. in naturally infected dogs. Veterinary Microbiology, Amsterdam, v. 70, n. 3-4, p. 239-250, 1999. 
CHAN, A. O. O. E-cadherin in gastric cancer. World Journal Gastroenterology, Beijing, v. 12, n. 2, p. 199203, 2006.

CHAN, A. O. O.; WONG, B. C. Y.; LAN, H. Y.; LOKE, S. L.; CHAN, W. K.; HUI, W. M.; YUEN, Y. H.; NG, I.; HOU, L.; WONG, W. M.; YUEN, M. F.; LUK, J. M. C.; LAM, S. K. Deregulation of E-cadherin-catenin complex in precancerous lesions of gastric adenocarcinomas. Journal of Gastroenterology and Hepatology. Melbourne, v. 18, n. 5, p. 534-539, may 2003.

CORREA, P. Helicobacter pylori and gastric cancer: state of the art. Cancer Epidemiology, Biomarkers \& Prevention, Philadelphia, v. 5, n. 6, p. 477-481, 1996.

CUI, G.; KOH, T. J.; CHEN, D.; ZHAO, C. M.; TAKAISHI, S.; DOCKRAY, G. J.; VARRO, A.; ROGERS, A. B., FOX, J. G., WANG, T. C. Over expression of glycine-extended gastrin inhibits parietal cell loss and atrophy in the mouse stomach. Cancer Research, Philadelphia, v. 64, n. 22, p. 8160-8166, 2004.

DE BOCK, M.; DECOSTERE A.; HELLEMANS. A.; HAESEBROUCK, F.; DUCATELLE, R. Helicobacter felis and Helicobacter bizzozeronii induce gastric parietal cell loss in mongolian gerbils. Microbes and Infection, Paris, v. 8, n. 2, p. 503-510, 2006.

DE FREITAS, D.; URBANO, M.; GOULAO, M. H.; DONATO, M. M.; BALDAIA, C.; MARTINS, M. I.; SOUTO, P.; GREGORITO, C.; FIGUEIREDO, P.; GOUVEIA, H.; ROMAOZINHO, J. M. The effects of Helicobacter pylori infection on apoptosis and cell proliferation in gastric epithelium. Hepatogastroenterology, Athens, v. 51, n. 57, p. 876-882, 2004.

DIXON, M. F.; GENTA, M. R.; YARDLEY, J. H.; CORREA, P. Classification and grading gastritis: the updated Sydney system. International workshop on the histopathology of gastritis, Houston 1994. American Journal Surgical Pathology, v. 20, n. 10, p. 1161-1181, 1996.

EATON, K. A.; DEWHIRST, F. E.; PASTER, B. J.; TZELLAS, N.; COLEMAN, B. E.; PAOLA, J.; SHERDING, R. Prevalence and varieties of Helicobacter species in dogs from random sources and pet dogs: animal and public health implications. Journal of Clinical Microbiology, Washington, v. 34, n. 12, p. 3165 3170, 1996.

HÄNNINEN， M. L.; HAPPONEN， I.; SAARI， S.; JALAVA, K. Culture and charactetistics of Helicobacter bizzozeronii, a new canine gastric Helicobacter sp. International Journal of Systematic Bacteriology, Ames, v. 46, n. 3, p. 160-166, 1996.
HAPPONEN， I.; LINDEN, J.; SAARI, S.; KARJALAINEN, M.; HÄNNINEN, M. L.; JALAVA, K.; WESTERMARCK, E. Detection and effects of helicobacters in healthy dogs and dogs with signs of gastritis. Journal of the American Veterinary Medical Association, Ithaca, v. 213, n. 12, p. 1767-1773, 1998.

HERMANNS, W.; KREGEL, K.; BREUER, W.; LECHNER, J. Helicobacter-like organisms: histopathological examination of gastric biopsies from dogs and cats. Journal of Comparative Pathology, v. 112, n. 3, p. 307-318, 1995.

INTERNATIONAL AGENCY FOR RESEARCH ON CANCER - IARC. Infection with schistosomes, liver flukes and Helicobacter pylori. In: IARC monographs on the evaluation of carcinogenic risks to humans. Lyon: IARC, 1994. v. 61, p. 218-220.

JALAVA，K.; KAARTINEN，M.; UTRIAINEN，M.; HAPPONEN, I.; HÄNNINEN, M. L. Helicobacter salomonis sp. nov.; a canine gastric Helicobacter sp. related to Helicobacter felis, and Helicobacter bizzozeronii. International Journal of Systematic Bacteriology, Ames, v. 47, n. 4, p. 975-982, 1997.

JALAVA， K.; ON, S. L.; HARRINGTON, C. S.; ANDERSEN, L. P.; HÄNNINEN, M.L. VANDAMME, P. A cultured strain of "Helicobacter heilmannii", a human gastric pathogen, identified as H. bizzozeronii: evidence for zoonotic potencial of Helicobacter. Emerging Infectious Diseases, Atlanta, v. 7, n. 6, p. 10361038, 2001.

LIU, Y.C.; SHEN, C. Y.; WU, H. S.; CHAN, D. C.; CHEN, C. J.; YU, J. C.; YU, C. P.; HARN, H. J.; SHYU, R. Y.; SHIH, Y. L.; HSIEH, C. B.; HSU, H. M. Helicobacter pylori infection in relation to E-cadherin gene promoter polymorphism and hypermethylation in sporadic gastric carcinomas. World Journal Gastroenterology, v. 11, n. 33, p. 5174-5179, 2005.

NEIGER, R.; TSCHUDI, M. E.; BURNENS, A.; GÖKE, B.; SCHMASSMANN, A. Diagnosis and identification of gastric Helicobacter species by polymerase chain reaction in dogs. Microbial Ecology in Health and Disease, Chichester, v. 11, n. 4, p. 234-240, 1999.

NEIGER, R.; SIMPSON K. W. Helicobacter infection in dogs and cats: facts and fiction. Journal of Veterinary Internal Medicine, Philadelphia, v. 14, n. 2, p. 125-133, 2000.

O'ROURKE, J. L.; DIXON, M. F.; JACK, A.; ENNO, A.; LEE, A. Gastric B- cell mucosa-associated lymphoid tissue (MALT) lymphoma in an animal model of "Helicobacter heilmannii" infection. Journal of Pathology, London, v. 203, n. 4, p. 896-903, 2004. 
OTTO, G.; HAZELL, S. H.; FOX, J. G.; HOWLETT, C. R.; MURPHY, J. C.; O’ROURKE, J. L.; LEE, A. Animal and public health implications of gastric colonization of cats by Helicobacter-like organisms. Journal of Clinical Microbiology, Washington, v. 32, n. 4, p. 1043-1049, 1994.

PARSONNET, J.; FRIEDMAN, G. D.; VANDERSTEEN, D. P.; CHANG, Y.; VOGELMAN, J. H.; ORENTREICH, N.; SIBLEY, R. K. Helicobacter pylori infection and the risk of gastric carcinoma. New England Journal of Medicine, Boston, v. 325, n. 16, p. 1127-1131, 1991.

PEEK JUNIOR, R. M.; WIRTH, H. P.; MOSS, S. F.; YANG, M.; ABDALLA, A. M.; THAM, K. T.; ZHANG, T.; TANG, L. H.; MODLIN, I. M.; BLASER, M. J. Helicobacter pylori alters gastric epithelial cell cycle events and gastrin secretion in Mongolian gerbils. Gastroenterology, Philadelphia, v. 118, n. 1, p. 48-59, 2000.

PEYROL, S.; LECOINDRE, P.; BERGER, I.; DELEFORGE, J.; CHEVALLIER, M. Differential pathogenic effect of two Helicobacter-like organisms in dog gastric mucosa. Journal of Submicroscopic Cytology and Pathology, Bologna, v. 30, n. 3, p. 425-433, 1998.

PLOTON, D.; MENAGER, M.; JEANNESSON, P.; HIMBER, G.; PIGEON, F.; ADNET, J. J. Improvement in the staining and in the visualization of the argyrophilic proteins of the nucleolar organizer regions at the optical level. Histochemical Journal, London, v. 18, n. 1, p. 5-14, 1986.

PREZIOSI, R.; SARLI, G.; MARCATO, P. S. Cell proliferation and apoptosis in the pathogenesis of oesophagogastric lesions in pigs. Research Veterinary Science, London, v. 68, n. 2, p. 189-196, 2000.

SAPIERZYŃSKI, R.; MALICKA, E. Effect of gastric Helicobacter-like organisms on gastric epithelial cell proliferation rate in dogs. Polish Journal of Veterinary Sciences, Olsztyn, n. 4, p. 275-281, 2004.

SIMPSON, K. W.; MCDONOUGH, P. L.; STRAUSSAYALI, D.; CHANG, Y. F.; HARPENDING, P.; VALENTINE, B. A. Helicobacter felis infection in dogs: effect on gastric structure and function. Veterinary Pathology, Basel, v. 36, n. 3, p. 237-248, 1999a.

SIMPSON, K. W.; STRAUSS-AYALI, D.; MCDONOUGH, P. L.; CHANG, Y. F.; VALENTINE, B. A. Gastric function in dogs with naturally acquired gastric Helicobacter spp. infection. Journal of Veterinary Internal Medicine, Philadelphia, v. 13, n. 6, p. 507-515, 1999b.
STEININGER, H.; STREITBERG, U. V.; WUNDER, I.; FALLER, G.; KIRCHNER, T. Inflammatory, preneoplastic, and neoplastic changes of the gastric mucosa. General \& Diagnostic Pathology, Jena, v. 141, n. 1, p. 15-19, 1995.

STRAUBINGER, R. K.; GREITER, A.; MCDONOUGH, S. P.; GEROLD, A.; SCANZIANI, E.; SOLDATI, S.; DAILIDIENE, D.; DAILIDE, G.; BERG, D. E.; SIMPSON, K. W. Quantitative evaluation of inflammatory and immune responses in the early stages of chronic Helicobacter pylori infection. Infection and Immunity, Bethesda, v. 71, n. 5, p. 2693-2703, 2003.

TAKEMURA, L. S.; CAMARGO, P. L.; ALFIERI, A. A.; BRACARENSE, A. P. F. R. L. Helicobacter spp. in cats: association of infecting species and epithelial proliferation within the gastric lamina propria. Journal of Comparative Pathology, London, v. 141, n. 2-3, p. $127-$ 134, 2009.

THIEDE, C.; MORGNER, A.; ALPEN, B.; WUNDISCH, T.; HERRMANN, J.; RITTER, M.; EHNINGER, G.; STOLTE, M.; BAYERDORFFER, E.; NEUBAUER, A. What role does Helicobacter pylori eradication play in gastric MALT and gastric MALT lymphoma. Gastroenterology, Philadelphia, v. 113, v.6, p. 61-64, 1997.

UEMURA, N.; OKAMOTO, S.; YAMAMOTO, S.; MATSUMURA, N.; YAMAGUCHI, S.; YAMAKIDO, M.; TANIYAMA, K.; SASAKI, N.; SCHLEMPER, R. J. Helicobacter pylori infection and the development of gastric cancer. New England Jounal of Medicine, Melbourn, v. 345, n. 11, p. 784-789, 2001.

VAN DEN BULCK, K.; DECOSTERE, A.; BAELE, M.; DRIESSEN, A.; DEBONGNIE, J.-C.; BURETT, A.; STOLTE, M.; DUCATELLE, R.; HAESEBROUCK, F. Identification of non-Helicobacter pylori spiral organisms in gastric samples from humans, dogs, and cats. Journal of Clinical Microbiology, Washington, v.43, n. 5, p. 2256-2260, 2005.

VAN DEN BULCK, K.; DECOSTERE, A.; BAELE, M.; BAÑADME, P.; MAST, J.; DUCATELLE, R.; HAESEBROUCK, F. Helicobacter cynogastricus sp. nov.; isolated from the canine gastric mucosa. International Journal of Systematic and Evolutionary, Reading, UK, v. 56, n. 7, p. 1559-1564, 2006.

YAMASAKI, K.; SUEMATSU, H.; TAKAHASHI, T. Comparison of gastric lesions in dogs and cats with and without gastric spiral organisms. Journal of the American Veterinary Medical Association, Washington, v. 212, n. 4, p. 529-533, 1998. 
YU, J.; EBERT, M. P.; MIEHLKE, S.; ROST, H.; XIA, H. H.; TALLEY, N. J. Apoptosis in gastric LENDECKEL, U.; LEODOLTER, A.; STOLTE, M.; BAYERDÖRFFER, E.; MALFERTHEINER, P. Alphacatenin expression is decreased in human gastric cancers and in the gastric mucosa of first degree relatives. Gut.,

London, v. 46, n. 5, p. 639-644, 2000. epithelium induced by Helicobacter pylori infections: implications in gastric carcinogenesis. The American Journal of Gastroenterology, New York, v. 96, n. 1, p. 16-26, 2001. 